\title{
Rural workload and factors associated with the use of medication by elderly people
}

\author{
Carga de trabalho rural e fatores associados ao uso de medicamentos por idosos \\ Carga de trabajo rural y factores asociados al uso de medicamentos por personas ancianas
}

Marta Regina Cezar-Vaz', Clarice Alves Bonow², Daiane Porto Gautério Abreu'1, Jordana Cezar Vaz ${ }^{3}$, Marlise Capa Verde Almeida de Mello ${ }^{1}$, Daiani Modernel Xavier ${ }^{1}$

How to cite this article:

Cezar-Vaz MR, Bonow CA, Abreu DPG, Vaz JC, Mello MCVA, Xavier DM. Rural workload and factors associated with the use of medication by elderly people. Rev Esc Enferm USP. 2018;52:e03374. DOI: http://dx.doi.org/10.1590/S1980-220X2017048303374

1 Universidade Federal do Rio Grande, Escola de Enfermagem, Rio Grande, RS, Brazil.

${ }^{2}$ Universidade Federal de Pelotas,

Departamento de Enfermagem em

Saúde Coletiva, Pelotas, RS, Brazil.

${ }^{3}$ Universidade José do Rosário

Vellano, Alfenas, MG, Brazil.

\begin{abstract}
Objective: Identify the prevalence and factors associated with the use of medication by elderly rural workers and verify the association between the use of medication and rural workload. Method: Cross-sectional, exploratory study, conducted among elderly rural workers from the state of Rio Grande do Sul. The data was collected through interviews, using a structured questionnaire. Results: Ninety-five elderly people participated in the study. Prevalence of medication use was 32\% higher among women than men, and the type of medication most used by women was for the nervous and musculoskeletal systems. One additional degree in the frustration level with farm work resulted in a $1 \%$ increase in the probability of elderly people using medication. Conclusion: It is necessary to consider strategies that seek to reduce the physical and mental demand of rural work, through investments in public policies that enable elderly people to reduce rural labor for subsistence purposes and, consequently, their workload.
\end{abstract}

DESCRIPTORS

Aged; Rural Workers; Workload; Drug Utilization; Public Health Nursing; Geriatric Nursing.
Corresponding author:

Marta Regina Cezar-Vaz

Escola de Enfermagem, Universidade

Federal do Rio Grande

Rua Visconde de Paranaguá, 102

Campus da Saúde - Área Acadêmica

CEP 96203-900 - Rio Grande, RS, Brazil

cezarvaz@vetorial.net
Received: 12/06/2017

Approved: 05/03/2018 


\section{INTRODUCTION}

In Brazil, according to the Statute for the Elderly, people are considered to be elderly at 60 years of age $\mathrm{e}^{(1)}$. Elderly people represented $13.7 \%$ of the total Brazilian population in 2014 , and population growth projections indicate that this percentage will rise to $18.6 \%$, in 2030 , and $33.7 \%$, in $2060^{(2)}$.

In Brazil, $16.1 \%$ of elderly people reside in rural areas, and $29.1 \%$ continue working $33.9 \%$ of the hours of the $\mathrm{day}^{(3)}$. Rural labor is intense and exhausting for all individuals and is even more apparent among elderly people.

A study conducted among elderly rural people from southern Brazil on functional capacity for daily life activities showed that, despite being retired, they continued working, since they needed an economic activity to keep them active ${ }^{(4)}$. Rural work includes light activities, such as spraying with a manual sprayer and taking care of the chickens; average activities, such as pulling weeds, harvesting with a scythe and grinding grain; and heavy activities, such as sowing and plowing the field and carrying loads on the head ${ }^{(5)}$. A study with Korean farmers demonstrated that workers who worked fewer hours during the day had fewer backaches ${ }^{(6)}$.

A study conducted in Europe found that rural workers over the age of 55 suffer the most from musculoskeletal diseases, related primarily to back pain ${ }^{(7)}$. In Indonesia, a study with 179 rural workers found that being older and having less than a 30-minute break, per work period, increases joint and bone pain, corresponding to $50.3 \%$ of the workers in that study ${ }^{(8)}$.

Heavy rural workloads, which cause wear to organs, can lead to a higher number of medications used by elderly people. Prevalence may be as high as $93 \%$ in terms of simultaneous medication use, characterized as polypharmacy among elderly people, who ingest over five medications per day, for more than three months ${ }^{(9)}$. This usage is not associated with age per se, but primarily with the presence and association of chronic conditions and wear to organs due to the aging process ${ }^{(9)}$.

Studies conducted in Brazil and China, comparing medication use among elderly people residing in rural and urban areas, found that elderly people from rural areas, despite having more chronic diseases, used fewer medications than elderly urban residents ${ }^{(10-11)}$. The justification for conducting the present study are: the increased number of elderly people; the tendency of these people to remain active and work for a longer time; the characteristics of rural labor, which is carried out in different weather conditions, with an intense routine and variety of tasks that can cause physical strain and, consequently, lead to the use of medications; and the scarce number of studies on elderly rural populations.

In addition, although there are various national and international studies on use of medication by elderly people and the associated factors, there are no specific investigations that address the relationship between workload and use of medication by elderly people, especially those living in rural areas, which also justifies the conducting of this study. In light of the above, and bearing in mind the lack of knowledge on this topic, this study seeks to identify the prevalence and factors associated with use of medication by elderly rural workers and determine the association between medication use and rural workload.

\section{METHOD}

This was an exploratory, cross-sectional study on the association between medication use and the rural workload of elderly people. The participant selection process was outlined in another production of the research group $^{(12)}$. For this study, only rural workers from the countryside of the state of Rio Grande do Sul, 60 years of age or older, were selected, representing an integration between two research groups - one linked to the socioenvironmental health of workers and the other to the health of elderly people.

The data was collected through interviews with the workers from March 2013 to April 2014. A structured questionnaire was used, addressing the characterization of the participants (age, sex, skin color, marital status and education), medication use and rural workload.

The medications were classified according to the National Medicines List (RENAME - Relação Nacional de Medicamentos Essenciais), adopted by the Ministry of $\mathrm{Health}^{(13)}$. In this classification, medications are divided according to the anatomical group or the system upon which they act and their chemical, therapeutic and pharmaceutical properties (cardiovascular system, digestive system and metabolism, nervous system, blood and hematopoietic organs, musculoskeletal system and systemic hormonal preparations, excluding sex hormones and insulins). In the case of medications not listed on the classification adopted by the Ministry of Health, the active substance, based on the commercial names, was identified and classified according to the anatomical group corresponding to the therapeutic use. For this, the Pharmaceutical Specialty Dictionary ${ }^{(14)}$ was used.

To define the workload required by agricultural tasks, the validated NASA Task Load Index (NASA-TLX) ${ }^{(15)}$ was used. This scale was applied in previous studies ${ }^{(16-17)}$ and measures workload through six demands: mental (think, choose, calculate and decide); physical (push, pull, carry and weed); temporal (time needed for performing activities - much/little); performance (the activities are performed with more/less quality and speed); effort (physical and mental state for carrying out activities); and frustration (motivation, satisfaction, discouragement and irritation). The participants graded each demand from one to 20 , to determine how heavy the workload was for each one.

The quantitative variables were described by mean and standard deviation or median and interquartile range, and the categorical variables by absolute and relative frequencies. To compare means, the Student t-test was applied for independent samples. In case of asymmetry (presence 
of extreme values), the Mann-Whitney test was used. In the comparison of proportions, Pearson's chi-square or Fisher's exact test were used.

To control confounding factors, Poisson Regression analysis was used. The criterion for incorporating a variable into the model was that it had a $\mathrm{p}$-value $<0.20$ in the bivariate analysis. The significance level adopted was $5 \%(\mathrm{p} \leq 0.05)$ and the analyses were performed with the Statistical Package for the Social Sciences (SPSS), version 21.0.

The study was approved by the Research Ethics Committee under Protocol No. 026/2013, and adhered to the recommendations in Resolution 466/2012.

\section{RESULTS}

The sample was composed of 95 elderly people, with a mean age of 67.3 years $( \pm 5.8)$, and a predominance in the age range of 60 to 69 years (65.3\%). Most were men (61.1\%), white $(94.7 \%)$, married (80\%) and had not completed their elementary education (93.9\%). Length of time working in agriculture was high; at least half of the sample had been farming for 50 years.

Of the total sample, 67 (70.5\%) used medication. The median of the number of medications used was 1 (percentiles $25-75: 0-3$ ). Figure 1 shows the type of medications used, where the most prevalent were those for the cardiovascular system (34.7\%).

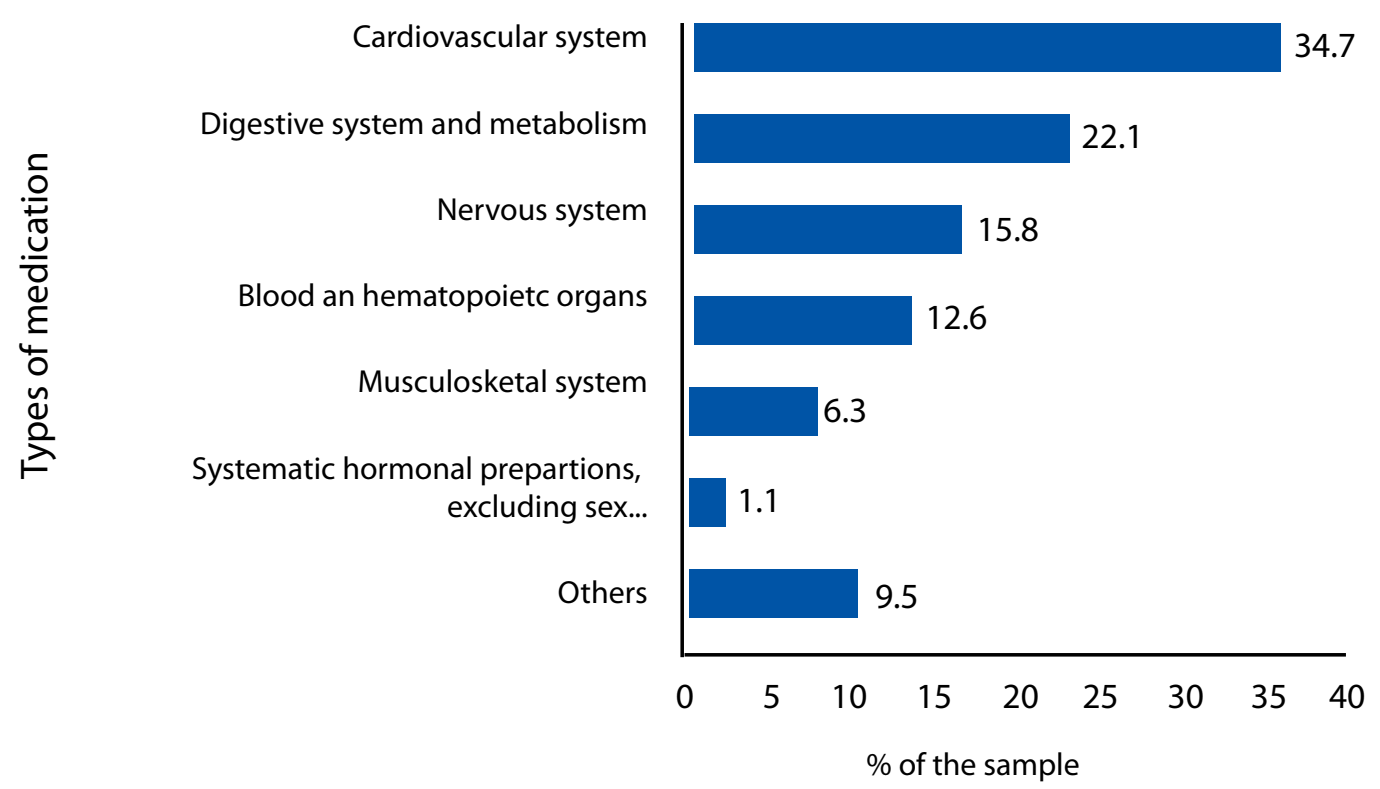

Figure 1 - Distribution of the sample by types of medications. Rio Grande do Sul, Brazil, 2013-2014.

Note: $(n=67)$.

The association between medication use and sex and age of the elderly people is presented in Table 1. A significantly higher prevalence of use was found among women than men, and the types of medication used the most by women were those that acted on the cardiovascular system, followed by those for the nervous and musculoskeletal systems. The number of medications used per day was also significantly higher among women.

There was no statistically significant association between age (under or over 70 years old) and use of medication, number of medications used per day and type of medication used (Table 1).
There was no statistically significant association between medication use and the scores assigned to the workload required for agricultural tasks (Table 2).

To control confounding factors, variables with $\mathrm{p}<0.20$ in the bivariate analysis were inserted into a multivariate Poisson Regression model. After adjustment, $\operatorname{sex}(\mathrm{p}=0.026)$ and frustration level related to the workload in agricultural tasks $(p=0.019)$ continued to be statistically associated with medication use. The prevalence of medication use was 32\% higher among women than men ( $\mathrm{PR}=1.32$; $\mathrm{CI} 95 \%: 1.03$ - 1.68). One additional degree in the frustration level with the workload in agriculture also resulted in a $1 \%$ increase in the probability of elderly people using medication ( $\mathrm{PR}=1.01$; CI 95\%: 1.00 to 1.01) (Table 3). 


\begin{tabular}{|c|c|c|c|c|c|c|}
\hline \multirow[t]{2}{*}{ Variables } & $\begin{array}{c}\text { Male } \\
(n=58)\end{array}$ & $\begin{array}{l}\text { Female } \\
(n=37)\end{array}$ & \multirow{2}{*}{$\mathbf{p}$} & $\begin{array}{c}<70 \text { years } \\
(\mathrm{n}=62)\end{array}$ & $\begin{array}{l}70 \text { years or more } \\
(n=33)\end{array}$ & \multirow[t]{2}{*}{$\mathbf{p}$} \\
\hline & n (\%) & n (\%) & & n (\%) & n (\%) & \\
\hline Use of medication - $n(\%)$ & & & 0.042 & & & 0.915 \\
\hline Yes & $36(62.1)$ & $31(83.8)$ & & $43(69.4)$ & $24(72.7)$ & \\
\hline No & $22(37.9)$ & $6(16.2)$ & & $19(30.6)$ & $9(27.3)$ & \\
\hline $\begin{array}{l}\text { Number of medications - } \\
\text { median (P25 - P75) }\end{array}$ & $1(0-2)$ & $2(1-3)$ & 0.002 & $1(0-2)$ & $1(0-3)$ & 0.834 \\
\hline \multicolumn{7}{|l|}{ Types of medications - n(\%) } \\
\hline Cardiovascular system & $17(29.3)$ & $16(43.2)$ & 0.242 & $20(32.3)$ & $13(39.4)$ & 0.639 \\
\hline Digestive system and metabolism & $14(24.1)$ & $7(18.9)$ & 0.731 & $13(21.0)$ & $8(24.2)$ & 0.915 \\
\hline Nervous system & $5(8.6)$ & $10(27.0)$ & 0.035 & $11(17.7)$ & $4(12.1)$ & 0.675 \\
\hline Musculoskeletal system & $1(1.7)$ & $5(13.5)$ & 0.032 & $4(6.5)$ & $2(6.1)$ & 1.000 \\
\hline $\begin{array}{l}\text { Systemic hormonal preparations, excluding sex } \\
\text { hormones and insulins }\end{array}$ & $0(0.0)$ & $1(2.7)$ & 0.389 & $1(1.6)$ & $0(0.0)$ & 1.000 \\
\hline Other & $5(8.6)$ & $4(10.8)$ & 0.732 & $6(9.7)$ & $3(9.1)$ & 1.000 \\
\hline
\end{tabular}

Table 2 - Association between use of medication and scores assigned to the workload required for agricultural tasks - Rio Grande do Sul, Brazil, 2013-2014.

\begin{tabular}{lccc}
\hline $\begin{array}{l}\text { Scores assigned to } \\
\text { workload required for } \\
\text { agricultural tasks }\end{array}$ & $\begin{array}{c}\text { Uses } \\
\text { medication }\end{array}$ & $\begin{array}{c}\text { Does not use } \\
\text { medication }\end{array}$ & p \\
\cline { 2 - 3 } & Mean \pm SD & Mean \pm SD & \\
\hline Mental Demand & $10.4 \pm 5.9$ & $10.6 \pm 6.4$ & 0.870 \\
Physical Demand & $14.3 \pm 4.7$ & $14.1 \pm 5.5$ & 0.829 \\
Temporal Demand & $12.5 \pm 6.1$ & $12.8 \pm 6.1$ & 0.856 \\
Performance & $12.3 \pm 6.6$ & $14.0 \pm 5.1$ & 0.171 \\
Effort level & $13.4 \pm 5.3$ & $13.3 \pm 5.4$ & 0.899 \\
Frustration level & $10.7 \pm 7.3$ & $7.8 \pm 7.1$ & 0.079 \\
\hline
\end{tabular}

Table 3 - Poisson regression analysis to assess factors independently associated with medication use - Rio Grande do Sul, Brazil, 2013-2014.

\begin{tabular}{lcc}
\hline Variables & $\mathbf{P R}_{\text {adjusted }}(\mathbf{C l} \mathbf{9 5} \%)$ & $\mathbf{p}$ \\
\hline Female & $1.32(1.03-1.68)$ & 0.026 \\
Frustration level & $1.01(1.00-1.01)$ & 0.019 \\
\hline
\end{tabular}

PR: prevalence ratio; CI95\%: confidence interval of $95 \%$.

\section{DISCUSSION}

The profile of the sample is similar to the findings of a national study by household sample, where there was a predominance among elderly rural people in the following aspects: male, in the age range of 60 to 69 years, with low education and married ${ }^{(2)}$.

Prevalence of medication use by elderly rural workers was slightly higher than the findings of a study conducted with elderly people residing in rural areas in Brazil and China ${ }^{(10-}$ ${ }^{11}$. It should be noted that in both of the studies used for comparison, elderly workers as well as elderly non-workers were included in the sample. The fact that the elderly people in the present study were workers may be associated with this higher prevalence, given that one additional degree in frustration demand with the agricultural workload resulted in a slightly higher probability of using medication.
The number of medications used per day (1) was lower, but very close to amounts in the studies conducted in Brazil (1.8) and China (1.7) $)^{(10-11)}$. This small difference may have been due to the fact that in the present study the median was used (since the data distribution was not from a normal sample), whereas in other studies the mean number of medications used per day was utilized.

The most prevalent type of medication in this study were those that acted on the cardiovascular system. This result coincides with the literature, which demonstrates that the medication used the most by elderly people are those for cardiovascular diseases, since they are the most frequent diseases in this population ${ }^{(18)}$. Although not the focus of the study, it is estimated that this result is due to the presence of risk factors that contribute to cardiovascular diseases among elderly people residing in rural communities, as seen in studies conducted in India ${ }^{(19)}$, China ${ }^{(20)}$ and Brazil ${ }^{(4)}$.

The results showed that women use more medications than men, with a $32 \%$ higher prevalence of use. A study carried out with elderly people in a rural area confirms this result, since the women had a $43 \%$ higher prevalence of use than men ${ }^{(11)}$. This tendency among women can be confirmed in another study conducted in 628 communities, with 142,042 adults, in relation to awareness, treatment and control of hypertension in men and women, where all the variables and rates were higher for women than men $^{(21)}$.

A study conducted in São Paulo on the use of potentially inappropriate medication for elderly people showed that the use of psychotropic drugs was higher among women than $m e n^{(22)}$. This study corroborates the findings of the present study, since one of the types of medication used the most by women were for the nervous system, such as psychotropic drugs ${ }^{(22)}$. A study with farm workers in a rural area in Brazil found that the odds of mental disorders were higher among women with moderate or higher levels of physical discomfort and frustration with agricultural work ${ }^{(17)}$. Mental disorders are the main cause for the use of medication that acts on the nervous system ${ }^{(23)}$. In the case of the present study, drugs that had secondary effects on the nervous system were 
not examined, but rather those that had some outcome in this system.

There was also a significant association between use of medication for the musculoskeletal system and sex. The female sex and age were risk factors for primary osteoporosis. Treatment for primary osteoporosis or the consequences thereof (pain resulting from fractures) is related to the use of medication $^{(24)}$.

The presence of osteoporosis can have a direct influence on creating limitations in actions that require greater flexibility of the body, such as farm labor. A study in Ethiopia, with 180 rural workers, demonstrated that women worked an average of 26 hours per week in agriculture, i.e., they were very involved in this type of work $^{(25)}$. In this sense, according to data from the national survey by household sample, only $18.9 \%$ of women continued working after 60 years of age. Among men, $41.9 \%$ continued working( ${ }^{(2)}$.

Women who work in farming do so with fewer technological resources and infrastructure than men and also have a longer workday, since they also do household chores ${ }^{(25)}$, which can lead to physical overload and pain in the musculoskeletal system. This may be even more significant among elderly women who, due to the aging process, have decreased bone mass, loss of muscle strength, less ligament elasticity and wear and tear on the joints, reducing the ability of women to perform their normal duties, which could lead to the use of medication for the musculoskeletal system ${ }^{(26)}$. The use of medication to alleviate pain, such as muscle relaxants, is inappropriate for the elderly, due to their sedative effect ${ }^{(23)}$.

There was no statistically significant association between age (under or over 70 years old) and medication use, number of medications used per day and type of medication used, which is consistent with the findings in the literature for elderly people residing in rural areas ${ }^{(11)}$.

The workload required for farm tasks with the use of medication was associated with frustration demand. Elderly people, with one additional degree in relation to this demand, had a $1 \%$ higher likelihood of using medication. Frustration is related to motivation, satisfaction, discouragement and irritation with farm work. Nevertheless, it is believed that work is beneficial for the health of elderly people, since studies show that work for elderly people in rural communities is a protective factor against a decline in basic and instrumental activities in daily life ${ }^{(27)}$.

A study conducted in Brazil with 259 farmers from two rural areas reported that repetitive work, followed by lifting heavy loads and incorrect posture, were among the main workloads identified by rural workers ${ }^{(28)}$. Although no association was found between physical, temporal, performance and effort demands and medication use, their association can result in physical overload, especially of the musculoskeletal system, and consequently lead to higher use of medication for this system. The use of this medication among women in the present study was significant, even though the association with workload was not significant.

There was also no association between mental demand (thinking, choosing, calculating and deciding) and use of medication in the study and, in the case of women, its use for the nervous system was significant, despite the fact that there was no significant association with workload. However, what is interesting is that, even without an association, mental overload exists. This needs to be better clarified in terms of the factors associated with it, for this group in particular. This could be explored further in other studies, since mental demand, in other studies, was found to be conducive to mental disorders, such as anxiety and stress ${ }^{(16)}$.

A limitation of the present study is that the data presented cannot be generalized due to the sample size. In relation to the factors associated with medication use by elderly people residing in rural areas, the study only examined the relationship between use, type and number of medications for the variables of sex and age. The data used was taken from the database of a larger study, and other information on the sample's sociodemographic and health profile (such as functionality and chronic diseases) was explored in other publications.

Knowing the prevalence of medication use, associated factors and the relationship between workload and medication use could facilitate the development of activities, such as group follow-up in personal and family environments, in collaboration with basic health teams, through interdisciplinary initiatives. Such initiatives can provide detailed assessments of medication use, effects, benefits and possible reductions or replacements by other options, characterized by a dynamic and continuous process.

The findings of the study constitute a public health issue and, for this reason, should be discussed in the nursing field, in order to improve specific knowledge on the care of elderly people and rural workers - as in the case that medication use is associated with the female sex and frustration with work. Therefore, it is proposed that further studies be conducted, through integrating intervention studies on the socioenvironmental health of workers and the health of elderly people.

\section{CONCLUSION}

The prevalence of medication use was $70.5 \%$ and the ones used the most were for the cardiovascular system. Prevalence of use was $32 \%$ higher among women than men. The ones used by women the most were for the cardiovascular system, followed by those for the nervous and musculoskeletal systems. It was also found that, albeit low (1\%), there is a probability that agricultural workload contributes to higher use of medication by elderly people.

It should be considered that the rural workload of elderly people is associated with higher use of medication. Therefore, knowing which demands (mental, physical, temporal, performance, effort or frustration) contribute more to increased workload may enable the development of health interventions to reduce, when possible, medication use. In the case of the present study, the physical demand had the highest mean among elderly people who use medication, and level of frustration with rural tasks was associated with greater use of medication. From this perspective, strategies should be contemplated that seek to reduce the physical and mental load of rural work, through investments in public policies that make it possible for elderly people to reduce subsistence-based rural labor and, consequently, their workload. 


\section{RESUMO}

Objetivo:Identificar a prevalência e os fatores associados ao uso de medicamentos por trabalhadores rurais idosos e verificar a associação entre o uso de medicamentos e a carga de trabalho rural. Método: Estudo transversal, exploratório, realizado com idosos trabalhadores rurais, do interior do estado do Rio Grande do Sul. A coleta de dados ocorreu por meio de entrevista, utilizando questionário estruturado. Resultados: Participaram do estudo 95 idosos. As mulheres apresentaram uma prevalência de uso de medicamentos $32 \%$ maior do que os homens, e os tipos de medicamentos mais utilizados por elas foram para o sistema nervoso e sistema musculoesquelético. Idosos com um grau a mais no nível de frustração com a carga de trabalho na agricultura tiveram um aumento de $1 \%$ na probabilidade de usar medicação. Conclusão: É necessário considerar estratégias que visem reduzir a carga física e mental do trabalho rural, por meio de investimentos em políticas públicas que possibilitem aos idosos reduzir o trabalho rural para subsistência e, por conseguinte, a sua carga de trabalho.

\section{DESCRITORES}

Idoso; Trabalhadores Rurais; Carga de Trabalho; Uso de Medicamentos; Enfermagem em Saúde Pública; Enfermagem Geriátrica.

\section{RESUMEN}

Objetivo: Identificar la prevalencia y los factores asociados con el uso de medicamentos por trabajadores rurales ancianos y verificar la asociación entre el uso de medicamentos y la carga laboral rural. Método: Estudio transversal, exploratorio, realizado con ancianos trabajadores rurales, del interior del Estado de Río Grande do Sul. La recolección de datos ocurrió mediante entrevista, utilizando cuestionario estructurado. Resultados: Participaron en el estudio 95 ancianos. Las mujeres presentaron una prevalencia de uso de medicamentos el 32\% mayor que los hombres, y los tipos de medicamentos más utilizados por ellas fueron para el sistema nervioso y sistema musculoesquelético. Ancianos con un grado más en el nivel de frustración con la carga de trabajo en la agricultura tuvieron un incremento del 1\% en la probabilidad de utilizar medicación. Conclusión: Es necesario considerar estrategias que tengan el fin de reducir la carga física y mental del trabajo rural, mediante inversiones en políticas públicas que posibiliten a los ancianos reducir el trabajo rural para subsistencia y, por consiguiente, su carga laboral.

\section{DESCRIPTORES}

Anciano; Trabajadores Rurales; Carga de Trabajo; Utilización de Medicamentos; Enfermería en Salud Pública; Enfermería Geriátrica.

\section{REFERENCES}

1. Brasil. Ministério da Saúde. Portaria n. 2.528, de 19 de outubro de 2006. Aprova a Política Nacional de Saúde da Pessoa Idosa [Internet]. Brasília; 2006 [citado 2017 nov. 30]. Disponível em: http://bvsms.saude.gov.br/bvs/saudelegis/gm/2006/prt2528_19_10_2006.html

2. Instituto Brasileiro de Geografia e Estatística. Pesquisa Nacional por Amostra de Domicílios: síntese de indicadores [Internet]. Rio de Janeiro; 2015 [citado 2017 nov. 30]. Disponível em: https://biblioteca.ibge.gov.br/visualizacao/livros/liv98887.pdf

3. Instituto Brasileiro de Geografia e Estatística. Síntese de indicadores sociais: uma análise da condição de vida da população brasileira [Internet]. Rio de Janeiro; 2014 [citado 2017 nov. 30]. Disponível em: https://biblioteca.ibge.gov.br/visualizacao/livros/liv94522.pdf

4. Pinto AH, Lange C, Pastore CA, Llano PMP, Castro DP, Santos F. Functional capacity to perform activities of daily living among older persons living in rural areas registered in the Family Health Strategy. Cien Saude Coletiva [Internet]. 2016 [cited 2018 Mar 16];21(11): 3545-55. Available from: http://www.scielo.br/scielo.php?pid=S1413-81232016001103545\&script=sci_arttext\&tlng=en

5. Mohanty SK. Grading of workload of male and female agricultural workers. J Agric Technol. 2016;3(1):63-70.

6. Jo H, Park H-w, Baek S, Kang EK. Low back pain in farmers: the association with agricultural work management, disability, and quality of life in Korean farmers. Hum Factors Ergon Manuf Serv Indust. 2017;27(3):156-65.

7. European Agency for Safety and Health at Work. European Risk Observatory Report. Work-related musculoskeletal disorders in the EU: facts and figures [Internet]. Luxembourg: European Union; 2010 [cited 2017 Nov 30]. Available from: https://osha.europa.eu/en/tools-andpublications/publications/reports/TERO09009ENC

8. Susanto T, Purwandari R, Wuryaningsih EW. Prevalence and associated factors of health problems among Indonesian farmers. Chinese Nurs Res. 2017;4(1):31-7.

9. Ramos LR, Tavares NUL, Bertoldi AD, Farias MR, Oliveira MA, et al. Polypharmacy and polymorbidity in older adults in Brazil: a public health challenge. Rev Saúde Pública [Internet]. 2016 [cited 2017 Dec 06];50 Suppl 2:1-13. Available from: http://www.scielo.br/scielo. php?script=sci_arttext\&pid=S0034-89102016000300308

10. Yang M, Lu J, Hao Q, Luo L, Dong B. Does residing in urban or rural areas affect the incidence of polypharmacy among older adults in western China? Arch Gerontol Geriatr. 2015;60(2):328-33.

11. Pizzol TSD, Pons ES, Hugo FN, Bozzetti MC, Sousa MLR, Hilgert JB. Uso de medicamentos entre idosos residentes em áreas urbanas e rurais de município no Sul do Brasil: um estudo de base populacional. Cad Saúde Pública [Internet]. 2012 [citado 2017 dez. 04];28(1):104-14. Disponível em: http://www.scielo.br/pdf/csp/v28n1/11.pdf

12. Cezar-Vaz MR, Bonow CA, Mello MCV, Silva MRS. Socio-environmental approach in nursing: focusing on rural labor and the use of pesticides. Rev Bras Enferm [Internet]. 2016 [cited 2017 Dec 04];69(6):1179-87. Available from: http://www.scielo.br/pdf/reben/v69n6/ en_0034-7167-reben-69-06-1179.pdf

13. Brasil. Ministério da Saúde. Relação Nacional de Medicamentos Essenciais [Internet]. Brasília; 2017 [citado 2018 mar. 16]. Disponível em: http://bvsms.saude.gov.br/bvs/publicacoes/relacao_nacional_medicamentos_rename_2017.pdf

14. Melo JMS. DEF 2016: Dicionário de especialidades farmacêuticas. 44ª ed. Rio de Janeiro: Publicações Científicas; 2016.

15. Cardoso MS, Gontijo LA. Avaliação da carga mental de trabalho e do desempenho de medidas de mensuração: NASA TLX e SWAT. Gest Prod [Internet]. 2012 [citado 2018 May 28];19(4):873-84. Disponível em: http://www.scielo.br/scielo.php?pid=S0104530X2012000400 015\&script=sci_abstract $\&$ tlng $=$ pt 
16. Cezar-Vaz MR, Bonow CA, Almeida MCV, Sant'Anna CF, Cardoso LS. Workload and associated factors: a study in maritime port in Brazil. Rev Latino Am Enfermagem [Internet]. 2016 [cited 2017 Dec 04];24:e2837. Available from: http://www.scielo.br/pdf/rlae/v24/0104-1169rlae-24-02837.pdf

17. Cezar-Vaz MR, Bonow CA, Silva MRS. Mental and physical symptoms of female rural workers: relation between household and rural work. Int J Environ Res Public Health. 2015;12(9):11037-49.

18. Prince MJ, Wu F, Guo Y, Robledo LMG, O'Donnell M, Sullivan R, et al. The burden of disease in older people and implications for health policy and practice. Lancet. 2015;385(9967):549-62.

19. Joshi R, Taksande B, Kalantri SP, Jajoo UN, Gupta R. Prevalence of cardiovascular risk factors among rural population of elderly in Wardha district. J Cardiovas Dis Res [Internet]. 2013 [cited 2017 Dec 04];4(2):140-6. Available from: https://www.ncbi.nlm.nih.gov/pmc/articles/ PMC3770113/

20. Song A, Liang Y, Yan Z, Sun B, Cai C, Jiang H, et al. Highly prevalent and poorly controlled cardiovascular risk factors among Chinese elderly people living in the rural community. Eur J Prev Cardiol. 2014;21(10):1267-74.

21. Chow CK, Teo KK, Rangarajan S, Islam S, Gupta R, Avezum A et al. Prevalence, awareness, treatment, and control of hypertension in rural and urban communities in high-, middle-, and low-income countries. JAMA. 2013;310(9):959-68. DOI: 10.1097/HJH.0000000000001326.

22. Baldoni AO, Ayres LR, Martinez EZ, Dewulf NL, Santos V, Pereira LR. Factors associated with potentially inappropriate medications use by the elderly according to Beers criteria 2003 and 2012. Int J Clin Pharm. 2014;36(2):316-24.

23. Sidani MA, Reed BC, Steinbauer J. Geriatric care issues: an American and an international perspective. Prim Care. 2017;44(1):e15-36.

24. Baccaro LF, Conde D, Costa-Paiva L, Pinto-Neto AM. The epidemiology and management of postmenopausal osteoporosis: a viewpoint from Brazil. Clin Interv Aging [Internet]. 2015 [cited 2017 Dec 04];10:583-91. Available from: https://www.ncbi.nlm.nih.gov/pmc/articles/ PMC4374649/

25. Harun ME. Women's workload and their role in agricultural production in Ambo district, Ethiopia. J Dev Agric Econ [Internet]. 2014 [cited 2017 Dec 04];6(8):356-62. Available from: http://www.academicjournals.org/article/article1405608226_Harun.pdf

26. Melo ACF, Nakatani AYK, Pereira LV, Menezes RL, Pagotto V. Prevalência de doenças musculoesqueléticas autorreferidas segundo variáveis demográficas e de saúde: estudo transversal de idosos de Goiânia/GO. Cad Saúde Colet [Internet]. 2017 [citado 2017 dez. 04];25(2):13843. Disponível em: http://www.scielo.br/pdf/cadsc/v25n2/1414-462X-cadsc-25-2-138.pdf

27. Fugiwara Y, Shinkai S, Kobayashi E, Minami U, Suzuki H, Yoshida H, et al. Engagement in paid work as a protective predictor of basic activities of daily living disability in Japanese urban and rural community-dwelling elderly residents: an 8-year prospective study. Geriatr Gerontol Int. 2016;16(1):126-34.

28. Rocha LP, Cezar-Vaz MR, Almeida MCV, Borges AM, Silva MR, Sena-Castanheira J. Workloads and occupational accidents in a rural environment. Texto Contexto Enferm [Internet]. 2015 [cited 2017 Dec 06];24(2):325-35. Available from: http://www.scielo.br/pdf/tce/ v24n2/0104-0707-tce-24-02-00325.pdf 